\title{
TINJAUAN KRITIS POLITIK DINASTI DI INDONESIA
}

\author{
Djoni Gunanto \\ Program Studi Ilmu Politik FISIP Universitas Muhammadiyah Jakarta \\ Corresponding Author, email: djoni.gunanto@umj.ac.id
}

\begin{abstract}
Abstrak
Tujuan penelitian, ini untuk mengungkap secara komprehensif tentang dinasti politik yang berkembang di Indonesia. Metode Penelitian ini merupakan studi literature review, dengan menelusuri produk hukum, jurnal, artikel, dan dokumen-dokumen. Teknik pengumpulan data dilakukan dengan mencatat sumber literatur. Analisis penelitian dilakukan menggunakan pedekatan kualitatif dengan menggunakan model analisis isi. Hasil Penelitian, Dinasti politik di Indonesia dilakukan dengan dua cara: by design dan by accident. Dinasti politik by design telah terbentuk sejak lama. Secara relasi, jejaring familisme dalam pemerintahan sudah kuat, sehingga kerabat yang masuk dalam pemerintahan atau terjun dalam kontestasi politik sudah diatur sedemikian rupa untuk merekayasa keberhasilan tujuannya. Adapun dinasti politik by accident terjadi dalam situasi suksesi pemerintahan yang secara tiba-tiba mencalonkan kerabat untuk menggantikannya demi menjaga kekuasaan informal erhadap penggantinya jika menang dalam kontestasi politik Kesimpulan. Politik dinasti sejatinya bisa diterima dan tidak dipersoalkan selama dalam pelaksanaan sistem perekrutan dan pemilihan calon dalam kontestasi politik di Indonesia berjalan secara adil dan profesional. Oleh karenanya, penentuan calon atau kandidat dalam kontestasi politik di Indonesia harus didasarkan pada sistem meritokrasi, yakni memberikan hak lebih kepada siapapun yang memiliki prestasi dan track record yang baik untuk menduduki kursi-kursi strategis dalam pemerintahan.
\end{abstract}

Kata Kunci: Politik, Dinasti, Kandidat, Pilkada

\section{Abstract}

The purpose of this research is to reveal comprehensively about the developing political dynasties in Indonesia. This research method is a literature review study, by exploring legal products, journals, articles, and documents. The data collection technique is done by noting literature sources. The research analysis was carried out using a qualitative approach using the content analysis model. The results of the study, political dynasties in Indonesia were carried out in two ways: by design and by accident. The political dynasty by design has been around for a long time. Relatively, the network of familism in government is already strong, so that relatives who enter the government or participate in political contestation have been arranged in such a way as to engineer the success of their goals. As for the political dynasty by accident occurs in a situation of succession of government which suddenly nominates relatives to replace them in order to maintain informal power over their successors if they win in political contestation. Dynastic politics can actually be accepted and not questioned as long as the recruitment and selection system for candidates in political contestation in Indonesia runs fairly and professionally. Therefore, the determination of candidates or candidates in political contestation in Indonesia must be based on a meritocratic system, which gives more rights to anyone with good achievements and track records to occupy strategic seats in government.

Keywords: Politics, Dynasty, Candidate, Regional Elections 
Jurnal Administrasi Negara

ISSN : 2598-4039 (Online)

ISSN : 2302-2231 (Print)

\section{Djoni Gunanto}

Program Studi Ilmu Politik FISIP Universitas

Muhammadiyah Jakarta

\section{PENDAHULUAN}

Politik berpengaruh sangat dominan dalam perjalanan sebuah bangsa dan negara. Dinamika politik yang positif dan konstruktif berdampak terhadap kemajuan bangsa dan negara. Dinamika politik yang negatif dan destruktif menjadikan suatu bangsa lemah dan mengalami kemunduran. Politik mempengaruhi berbagai hal dalam kehidupan bernegara, bahkan dapat mengubah tata dan sistem suatu negara. Sebagaimana dalam pandangan Harold Laswell, politik sebagai studi dalam mempelajari berbagai ruang lingkup negara, termasuk dalam pembentukan dan pembagian kekuasaan.

Dalam negara demokrasi, dinasti politik telah muncul sejak lama. Hal itu menimbulkan kekhawatiran adanya ketidaksetaraan dalam distribusi kekuasaan politik sehingga dapat mencerminkan ketidaksempurnaan dalam reperesentasi demokratis dalam politik, yang disebut kekuasaan melahirkan kekuatan. Dinasti polititk adalah fenomena umum dan telah lahir di negara-negara demokrasi modern. Di Amerika Serikat, prevalensi dinasti di Kongres lebih tinggi dibandingkan dengan pekerjaan lain. Hasil pemilihan paruh waktu di Filipina pada tahun 2013 menunjukkan bahwa dari 80 persen provinsi, yang keluarga politik ikut andil dalam pemilihan, 74 persen anggota dewan wakil rakyat terpilih berasal dari keluarga dinasti tersebut.

Mengingat kembali kekhawatiran Mosca, bahwa setiap kelas menampilkan kecenderungan untuk menjadi turun temurun, bahkan ketika dalam kondisi politik terbuka untuk siapapun, kedudukan keluarga penguasa akan dianugerahi berbagai keuntungan.

Negara demokrasi sejatinya harus membuka kran politik seluas mungkin untuk memastikan rakyat terlibat aktif dalam proses politik. Ruang partisipasi untuk masyarakat dalam kontestasi politik regional hingga nasional harusnya sangat terbuka. Namun faktanya, dengan munculnya politik dinasti telah menghambat partisipasi masyarakat karena status atau hak sosialnya yang jauh berbeda dengan keluarga petahana. Politik dinasti telah merusak makna demokrasi yang sejati, yakni kekuasaan politik atau pemerintahan yang dijalankan dari rakyat, oleh rakyat, dan untuk rakyat. Politik dinasti juga memunculka pragmatisme politik dengan mendorong famili atau kerabat penguasa untuk menjadi pejabat publik.

Dalam kontestasi politik tentu diwarnai dengan berbagai dinamika, mulai dari proses pemilihan pejabat negara untuk menduduki pemerintahan hingga dinamika dalam menjalankan kekuasaan. Dalam hal tersebut, partai politik (parpol) menjadi aktor utama, 
Jurnal Administrasi Negara

ISSN : 2598-4039 (Online)

ISSN : 2302-2231 (Print)

\section{Djoni Gunanto}

Program Studi Ilmu Politik FISIP Universitas

Muhammadiyah Jakarta sehingga dinamika yang sering menjadi sorotan adalah peran parpol dalam proses mendapatkan kekuasaan, mulai dari pembentukan koalisi hingga penentuan calon. Sebelum kontestasi politik dimulai, penentuan calon oleh parpol dalam pilkada atau pemilu selalu menjadi pembahasan penting, utamanya fenomena terjadinya politik dinasti, yakni munculnya calon yang berasal dari keluarga tokoh parpol. Disadari atau tidak, politik dinasti dalam tubuh parpol tumbuh berkembang dalam perpolitikan Indonesia.

Di tubuh partai politik di Indonesia tidak dapat dipungkiri adanya oligarki yang dapat mempengaruhi mekanisme pencalonan dan kandidasi sehingga tidak berjalan sebagaimana mestinya. pencalonan kandidat oleh partai politik seringkali seringkali berdasarkan keinginan elit partai politik, bukan berdasarkan kualitas dan integritas calon. Dinasti politik memperkuat jaringan kekuasaan mulai dari tingkat daerah hingga pusat, yang orientasinya mempertahankan kekuasaan dalam tubuh partai politik. Akhirnya dinasti politik menguasai sekaligus mematikan demokrasi dalam partai politik.

Tumbuh berkembangnya dinasti politik selalu menjadi pro-kontra. Secara umum, dinasti politik dipandang berpotensi memicu penyalahgunaan kekuasaan. Namun di sisi lain juga berkembang pandangan bahwa adanya larangan bagi keluarga petahana atau penguasa untuk ikut serta dalam kontestasi politik merupakan pelanggaran hak asasi manusia dan melanggar konstitusi warga negara.

\section{METODE PENELITIAN}

Penelitian ini berfokus pada pembahasan politik dinasti di Indonesia. Penelitian ini merupakan studi literature review, dengan menelusuri produk hukum, jurnal, artikel, dan dokumen-dokumen yang terkait dengan fokus penelitian. Teknik pengumpulan data dilakukan dengan mencatat sumber literatur yang meliputi peraturan perundang-undangan mengenai pemilihan umum (pemilu) dan pemilihan kepala daerah (pilkada), buku dan jurnal yang berkaitan dengan politik dinasti dan pemilu dan pilkada, juga opini-opini dan berita di mediamedia massa. Analisis penelitian dilakukan menggunakan pedekatan kualitatif dengan menggunakan model analisis isi.

\section{HASIL DAN PEMBAHASAN}

\section{Politik Dinasti dan Kontestasi Politik}

Politik dinasti dan dinasti politik merupakan dua hal berbeda. Politik dinasti adalah proses mobilisasi regenerasi kekuasaan kaum oligarki yang bertujuan untuk meraih atau melanggengkan kekuasaan. Dinasti politik ialah sistem reproduksi 
Jurnal Administrasi Negara

ISSN : 2598-4039 (Online)

ISSN : 2302-2231 (Print)

\section{Djoni Gunanto}

Program Studi Ilmu Politik FISIP Universitas

Muhammadiyah Jakarta kekuasaan yang mengandalkan familisme atau hubungan kekerabatan. Dinasti politik dapat disebut sebagai sistem yang bertentangan dengan demokrasi karena telah membatasi ruang ligkup demokrasi yang seharusnya membuka peluang dalam berpolitik seluas-luasnya.

Dinasti politik di Indonesia sudah muncul sejak orde lama, yakni dalam keluarga presiden pertama Indonesia, Soekarno. Keturunan Soekarno meneruskan profesinya sebagai politisi: Megawati Soekarnoputri, Sukmawati, dan Guruh Soekarno. Fenomena dinasti politik juga terlihat dalam keluaraga Gusdur (KH. Abdurrahman Wahid), yakni terjunnya saudara-saudara kandungnya, juga anak kandungnya ke dalam dunia politik. Begitu juga Megawati Soekarnoputri yang terlihat ada gejala dinasti politik dengan terlibat aktifnya Puan Maharani dalam perpolitikan di Indonesia hingga akhirnya menjadi ketua Dewan Perwakilan Rakyat Republik Indonesia (DPR RI). Pada keluarga Presiden Susilo Bambang Yudhoyono (SBY) pun demikian. Agus Harimurti Yudhoyono (AHY), Eddie Baskoro, Hartanto Edhie Wibowo, Agus Hermanto, Sartono Hutomo, Dwi Astuti Wulandari, dan Agung Budi Santosa merupakan sederatan keluarga SBY yang terjun dalam perpolitikan di Indonesia.
Hingga saat ini, dinasti politik terus tumbuh berkembang. Dinasti politik, yang oleh masyarakat dianggap sebagai virus demokrasi pada awalnya muncul optimisme penyakit ini akan hilang dengan terpilihnya Jokowi sebagai penguasa karena dia bukan berasal dari keluarga elit politik. Namun anggapan itu ternyata salah, karena Jokowi telah tertular virus elit politik masa lalu yang melakukan nepotisme dan politik dinasti. Jokowi telah merestui anaknya, Gibran Rakabuming Raka, menjadi calon walikota Solo. Tidak hanya putranya, menantu Jokowi, Bobby Nasution, juga disinyalir akan maju sebagai wali kota Medan. Bahkan Siti Nur Azizah, anak wakil Presiden RI 2019-2020, Ma'ruf Amin, mencalonkan diri dalam pemilihan Wali Kota Tangerang Selatan 2020.

Pada level daerah, dinasti politik juga tumbuh subur. Berdasarkan riset yang dirilis oleh Indonesia Corruption Watch (ICW), bahwa pada 2010 termasuk menjadi sorotan utama karena terdapat beberapa kepala daerah yang terpilih dan bersatatus sebagai kerabat kepala daerah sebelumnya: Bupati Kendal, Widya kandi Susanti (istri Bupati Kendal, Hendy Boedoro); Bupati Kutai Kartanegara, Rita Widyasari, anak kandung mantan Bupati Kutai Kartanegara, Syaukani HR; Bupati Lampung Selatan, RyckoMendoza, putra Gubernur Lampung, Sjachruddin 
Jurnal Administrasi Negara

ISSN : 2598-4039 (Online)

ISSN : 2302-2231 (Print)

\section{Djoni Gunanto}

Program Studi Ilmu Politik FISIP Universitas

Muhammadiyah Jakarta
ZP; Bupati Pesawaran, Aries Sandi Dharma, anak Bupati Tulang Bawang; Bupati Tabanan, Bali, Ni Putu Eka Wiryastuti, anak Bupati sebelumnya; Bupati Kediri, Haryanti Sutrisno, merupakan istri Bupati; Walikota Cilegon, Tubagus Iman Ariyadi, merupakan anak Walikota; Bupati Batul, Yogyakarta, Sri Suryawidati, istri Bupati sebelumnya, Idham Samawi; Bupati Indramayu, Anna Sophanah, mantan istri Bupati sebelumnya. Selain itu, Syahrul Yasin Limpo, Gubernur Sulawesi Selatan 2008-2012, mempunyai saudara-saudara yang menjadi pejabat: Ikhsan Yasin Limpo, Bupati Gowa 20052010; Haris Yasin Limpo, anggota DPRD kota Makassar 2004-2009; Tenri Olle, anggota DPRD Sulawesi Selatan 20092014. Terdapat juga anak Syahrul Yasin Limpo, Indira Thita Chunda, menjadi anggota DPR 2009-2014, dan keponakannya, Adnan Purichta, menjadi anggota DPRD Sulawesi Selatan 2009-2014.

Fenomena dinasti politik juga terjadi di Provinsi Banten, bahkan termasuk yang paling berhasil dalam membangun dinasti politik. Keluarga mantan gubernur Banten, Ratu Atut Chosiyah tercatat paling sering terpilih dalam pemilu atau pilkada. Dinasti Ratu Atut dimulai dari ayahnya, Tubagus Chasan. Tubagus aktif di partai politik, Golkar, yang kemudian jejaknyya diikuti oleh anak-anaknya sebagai kendaraan polittik. Ratu Atut menjabat sebagai wakil Gubernur Banten pada 2002, kemudian menang pada Pilkada Banten pada 2006 dan 2011. Jejak politik Ratu Atut diikuti oleh anggota keluarganya, mulai dari saudara, suami, ipar, mertua, ibu tiri, hingga anak-anaknya. Hikmat Tommet, suami Ratu Atut, terpilih sebagai anggota DPR RI periode 2009-2014. Andika Hazrumy, anak pertama Ratu Atut, menjadi Wakil Gubernur Banten periode 2017-2022. Andiara Aprilia, anak kedua Ratu Atut, menjadi Dewan Perwakilan Daerah (DPD) Banten periode 2019-2024. Tanto W, menantu Ratu Atut, menjadi Wakil Bupati Pandeglang periode 2015-2020. Ade Rossi Khaerunisa, menantu Ratu Atut, DPRD Kota Serang. Ratu Tatu Chasanah, adik kandung Ratu Atut, menjadi Bupati Serang periode 20152020. Tubagus Haerul Jaman, adik tiri Ratu Atut, menjadi anggota DPR RI periode 2019-2024. Ratu Ria Maryana, adik tiri Ratu Atut, sebagai Ketua DPD Golkar Kota Serang periode 2020-2025 sekaligus Wakil Ketua DPRD Kota Serang. Ratu Lilis, adik tiri Ratu Atut, mantan Ketua DPD Golkar Kota Serang. Airin Rachmi Diany, adik ipar Ratu Atut, Wali Kota Tangerang Selatan periode 2016-2021. Aden Abdul Cholik, adik ipar Ratu Atut, DPRD Banten. Ratna Kumalasari, ibu tiri Ratu Atut, menjadi anggota DPRD Pandeglang.

Tidak hanya keluarga Gubernur Ratu Atut, beberapa kerabat kepala 
Jurnal Administrasi Negara

ISSN : 2598-4039 (Online)

ISSN : 2302-2231 (Print)

\section{Djoni Gunanto}

Program Studi Ilmu Politik FISIP Universitas

Muhammadiyah Jakarta daerah di Banten juga teridentifikasi membangun dinasti politik: $\mathrm{Tb}$ Iman Aryadi, putra walikota Cilegon, menjabat sebagai DPR RI; Ahmed Zaki, putra Bupati Tangerang, sebagai DPR RI; Iti Octavia Jayabaya, putri Bupati Lebak, menjabat sebagai DPR RI; Diana Jayabaya, anak Bupati Lebak, sebagai anggota DPRD Provinsi Banten; Mulyanah, adik Bupati Lebak, menjadi anggota DPRD Lebak; Agus R Wisas, adik ipar Bupati Lebak, menjadi anggota DPRD Banten; Irna Narulita, istri Bupati Pandeglang, menjabat sebagai anggota DPR RI.

Fenomena dinasti politik yang juga banyak disorot terjadi di Pulau Madura, tepatnya di Kabupaten Bangkalan. Tokoh terkenal di Bangkalan bahkan di seluruh Madura yaitu RKH. Fuad Amin. Beliau lahir dari keluarga tokoh agama dan aktif di dunia perpolitikan. Karir politiknya berawal sejak terpilihnya menjadi ketua DPC PPP Kabupaten Bangkalan pada 1996. Fuad Amin melanjutkan jejak ayahnya, Kyai Amin Imron, dalam jabatan tersebut. Kyai Amin Imron merupakan tokoh senior PPP Bangkalan dan merupakan anggota DPR RI pada era Orde Baru. RKH Fuad Amin terpilih menjadi Bupati Bangkalan untuk periode 2003-2008. Fuad Amin hijrah dari Partai Persatuan Pembangunan (PPP) ke Partai Kebangkitan Bangsa (PKB) setelah ditawari menjadi pengurus DPP PKB sebagai Dewan
Syuro oleh KH. Abdurrahman Wahid (Gus Dur). Dalam karir politiknya, Fuad Amin mendapat dukungan dari berbagai pihak, dari fraksi mayoritas anggota parlemen hingga fraksi TNI/Polri dan FPAU.

Pada Pilkada 2008, Fuad Amin kembali mencalonkan diri sebagai Bupati Bangkalan, dan kemenanganpun diraih dengan mudah dan maksimal, dengan pencapaian suara mencapai 80,79 persen. Fuad Amin membangun dinasti politik dengan mengikutsertakan putranya, Makmun Ibnu Fuad, dalam kontestasi politik. Alhasil, Makmun telah menduduki jabatan sebagai anggota DPRD Kabupaten Bangkalan sejak berumur 25 Tahun. Setelah Fuad Amin tidak bisa lagi mencalonkan diri sebagai Bupati Bangkalan, beliau mencalonkan Makmun Ibnu Fuad dalam pilkada Kabupaten Bangkalan, dan berakhir dengan kemenangan mutlak sehingga terhitung memecahkan rekor karena meraup kemenangan yang mencapai hingga 90 persen suara.

Sebagai tokoh yang sangat disegani dan dihormati oleh para tokoh dan masyarakat Madura, Fuad Amin tidak takut jika harus berpindah-pindah kendaraan politik. Pada saat PKB mengalami konflik besar, Fuad Amin memutuskan untuk hijrah ke Partai Gerakan Indonesia Raya (GERINDRA). Kehadiran Fuad Amin di Partai Gerindra bepengaruh besar, terbukti 
Jurnal Administrasi Negara

ISSN : 2598-4039 (Online)

ISSN : 2302-2231 (Print)

\section{Djoni Gunanto}

Program Studi Ilmu Politik FISIP Universitas

Muhammadiyah Jakarta
Gerindra berhasil memenangkan Pemilu di Kabupaten Bangkalan, dengan memperoleh 10 kursi dari total 45 kursi di DPRD Kabupaten Bangkalan. Fuad Amin menjadi ketua dewan, sehingga lembaga eksekutif dan legislatif Kabupaten Bangkalan dikuasai oleh dinasti Fuad Amin. Makmun Ibnu Fuad menjadi Bupati Bangkalan dan Fuad Amin menjadi Ketua DPRD Kabupaten Bangkalan.

Marcuz Mietzner menilai bahwa kecenderungan politik dinasti cukup menguat dalam politik kontemporer di Indonesia. Menurutnya, praktik politik dinasti merupakan penyakit dalam demokrasi. Politik dinasti melemahkan controlling terhadap pemerintah yang merupakan hal penting dalam negara demokrasi. Pengamat politik banyak menyebut dinasti politik dengan oligarki politik, karena dalam sistem ini elit politik berbasikan keterikatan darah atau perkawinan. $\mathrm{Di}$ Indonesia, elit politik memiliki kemampuan dalam mempengaruhi proses pembuatan keputusan politik. Dalam kontestasi politik, mereka relatif mudah dalam memenangkan kekuasaan.

\section{Berkembanganya Dinasti Politik di Indonesia}

Dinasti politik di Indonesia muncul dan tumbuh berkembang sejak orde lama. Namun dalam ranah lokal, dinasti politik muncul sejak pertamakali pemilukada langsung diberlakukan pada tahun 2005 maupun implementasi otonomi daerah tahun 2001. Sebagai wujud demokratisasi lokal pada saat itu berbagai elit politik lokal muncul untuk mengooptasi kedua proses tersebut, yang kemunculan para elit tersebut dikenal dengan reorganisasi kekuasaan. Pada masa order baru, pusat membatasi kekuasaan para elit. Mekanisme yang dilakukan cenderung pada pengangkatan secara langsung. Elit lokal yang pro dengan Orde Baru mendapat keistimewaan, sedangkan yang kontra bisa tersingkir di arena politik lokal di daerahnya.

Momentum transisi dari otoriaritanisme menuju demokrasi yang ditandai dengan kebijakan otonomi daerah dimanfaatkan betul oleh kelompok dua kelompok, pro dan kontra terhadap Orde Baru, untuk berkuasa secara penuh di daerahnya dalam kontestasi untuk menjadi elit pemenang maupun membangun sinergi yang biasanya melalui jalur perkawinan. Tidak heran jika otonomi daerah kemudian memunculkan rajaraja kecil di daerah. Perkembangan politik lokal Orde Baru kemudian dikenal dengan istilah 'Cendanaisasi' lokal. Istilah cendanaisasi merujuk pada Keluarga Cendana semasa 32 tahun kepemimpinan Presiden Soeharto yang sangat berkuasa dalam ekonomi-politik Indonesia. Mulai dari anak, menantu, kemenakan, hingga kerabat-kerabat lainnya menguasai pos-pos sraegis 
Jurnal Administrasi Negara

ISSN : 2598-4039 (Online)

ISSN : 2302-2231 (Print)

\section{Djoni Gunanto}

Program Studi Ilmu Politik FISIP Universitas

Muhammadiyah Jakarta pemerinahan, sehingga dinasti Keluarga Cendana berkuasa selama tiga dekade. Pola demikian menjadi inspirasi keluarga elit saat ini, menjalankan politik dinasti dengan menempatkan kerabat pada posisi-posisi straegis pemerintahan.

Dinasti politik di Indonesia dilakukan dengan dua cara: by design dan by accident. Dinasti politik by design telah terbentuk sejak lama. Secara relasi, jejaring familisme dalam pemerintahan sudah kuat, sehingga kerabat yang masuk dalam pemerintahan atau terjun dalam kontestasi politik sudah diatur sedemikian rupa untuk merekayasa keberhasilan tujuannya. Adapun dinasti politik by accident terjadi dalam situasi suksesi pemerintahan yang secara tibatiba mencalonkan kerabat untuk menggantikannya demi menjaga kekuasaan informal erhadap penggantinya jika menang dalam kontestasi politik.

\section{Familisme Dinasti Politik}

Familisme sebagai budaya politik merupakan ketergantungan ang terlalu besar terhadap ikatan keluarga, yang melahirkan kebiasaan menempatkan keluarga dan ikatan kekerabatan pada kedudukan yang lebih tinggi daripada kewajiban sosial lainnya. Familisme juga dapat dipahami sebagai new social order, yaitu dorongan psikologis bagi seseorang untuk mampu berkarir dalam dua ranah sekaligus: ranah publik sebagai birokrat dan ranah privat sebagai korporat-swasta. Pada kasus Eropa pertengahan menujukkan bahwa individualisme sesorang lemah dalam ekspresi berpolitik jika tidak melibatkan kerabat di dalamnya. Ekspresi berpolitik sebenarnya bukan berorientasi mengejar kekuasaan, tetapi untuk menjaga artikulasi ide-ide dalam membanngun masarakat. Melalui jejarig familisme itulah ide-ide tersebut akan terjaga dan terealisasi melalui kerabatkerabat lainnya yang terjun dalam dunia politik.

Pada prinsipnya, politik dinasti seharusnya lebih mengarah kepada perilaku menjaga moral, bukan sekadar mengejar kekuasaan. Di Eropa atau Amerika Utara memiliki konsep familisme yang berbeda dari negaranegara dunia ketiga. Familisme dipahami sebagai langkah dqlam menumbuhkan sikap favoritisme, nepotisme, seksionalisme, maupun regionalisme, yang berlandaskan pada sikap semangat dalam upaya menjaga dan mewujudkan kepentingan secara kolektif. Namun demikian, hubungan darah tidaklah menjadi patokan utama dalam mendorong kerabat untuk terjun dalam dunia politik. Politik dinasti di Eropa/Amerika Utara didasarkan pula pada tuntutan masyarakat, lingkungan, maupun kondisi tertentu yang kemudian menjadi faktor terbentuknya dinasti politik. Adanya patrimonialisme 
Jurnal Administrasi Negara

ISSN : 2598-4039 (Online)

ISSN : 2302-2231 (Print)

\section{Djoni Gunanto}

Program Studi Ilmu Politik FISIP Universitas

Muhammadiyah Jakarta maupun nepotisme merupakan salah satu varian dari budaya politik familisme. Terdapat tiga bentuk familisme dalam dinasti politik:

Familisme (familism), yakni dinasti politik yang didasarkan pada hubungan darah secara langsung dalam keluarga (consanguinity) dan hubungan perkawinan (marriage) dengan klan lainnya. Posisi keluarga politik yang lemah akan menguntung keluarga politik yang lebih kuat karena dianggap dapat menjaminn eksistensi yang lemah. Loyalitas, kepatuhan, dan solidaritas keluarga merupakan poinpoin penting familisme dalam mempengaruhi corak dinasti politik. Contoh kasus dinasi politik familisme seperti yang terjadi di Filipina. Terdapat 105 dinasti politik yang tumbuh subur di Filipina, baik di tingkat lokal maupun nasional. Tidak hanya dalam ranah eksekutif, tapi juga berkembang di ranah legislatif, yudikatif hingga lembaga penegakan hukum lainnya.

Quasi-familisme, yang didasarkan pada sikap afeksi dan solidaritas anggota keluarga dalam struktur kekuasaan. Dalam hal ini, dimensi dinasti politik tidak hanya dalam ranah keluarga inti, melainkan mencakup cabang keluarga lainnya yang tidak satu keturunan darah, namun secara artifisial memiliki sistem kekerabatan. Karenanya, seluruh anggota famili berusaha menampakkan diri dengan simbol-simbol tertentu agar mendapat legitimasi dari keluarga lainnya. Dalam quasi-familisme, yang digalang adalah proses solidaritas bagi anggotanya, baik yang berada di ranah formal maupun informal. Sebab itulah quasi-familisme berkembang seperti kekuatan oligarkis yang mampu memberikan pengaruh di berbagai lini kehidupan.

Egoisme-familisme, yang didasarkan pada pemenuhan aspek fungsionalisme dibanding hanya menuruti garis keurunan maupun ikatan darah. Egoisme dalam konteks ini dapat dipahami dalam dua hal: dari segi kepala daerah dan masyarakat. Egoisme kepala daerah cenderung mendahulukan keluarga dalam distribusi jabatan publik maupun suksesi pemerintahan daripada publik. Kepala daerah yang telah digantikan masih memiliki pengaruh secara langsung tidak langsung, sehingga timbul tafsir bahwa pengganti pemerinntah demisioner merupakan bayangan. Hal itu dilakukan berorientasi pada pengamanan program-program kebijakan ataupun proses penganggarann yang telah dilakukan.

Dari sisi masyarakat, egoisme mengarah pada kecenderungan untuk menjaga agar famili tertentu tetap berkuasa. Hal itu terjadi karena peguasa berhasil membina dan memperkuat kohesi sosial dengan masyarakat melalui serangkaian program kebijakan 'gentong babi' (pork barrel politics), 
Jurnal Administrasi Negara

ISSN : 2598-4039 (Online)

ISSN : 2302-2231 (Print)

\section{Djoni Gunanto}

Program Studi Ilmu Politik FISIP Universitas

Muhammadiyah Jakarta meskipun sarat dengan perilaku korupsi karena menyangkut usaha politisasi anggaran. Adanya program populis tersebut berhasil menanamkan romantisme dan jejaring politik secara efektif dan efisien kepada maasyarakat. Penguasa dinilai berhasil mengeluarkan kebijakan populis ataupun budaya permisif yang masih kuat di masyarakat.

\section{Dinasti Politik dalam Negara Demokrasi}

Dinasti politik pada dasarnya tidak ada dalam demokrasi, walaupun sejarah mencatat dalam negara-negara demokrasi modern fenomena dinasti politik tumbuh berkembang. Negara demokrasi menjunjung tinggi hak seluruh warga negara untuk memilih dan dipilih. Tidak dibenarkan jika mengatasnamakan dan konstitusi lantas kehidupan politik didominasi oleh sekelompok golongan tertentu, karena negara adalah milik bersama. Setiap warga negara berhak menduduki jabatan politik selama mendapat kepercayaan oleh rakyat. Proses pengawasan dan pembatasan yang berlaku selama ini hanya diserahkan kepada landasan etik terkait kepatutan dan kepantasan. Fakta yang terjadi di lapangan justru politik dinasti berkembang dan subur dalam lingkup negara demokrasi kita. Sistem yang berlaku dalam politik dinasti berdasarkan kedekatan secara personal bukan atas dasar kapasitas dan kualitas. Hal itu mencemari keberlangsungan perpolitikan yang berkembang. Dinasti politik yang berkembang di Indonesia menjadi ancaman keberlangsungan dan masa depan perpolitikan di Indonesia. Selain memotong hak rakyat juga dapat melahirkan pemimpin yang tidak kompeten serta melahirkan neo-tirani (tirani dalam bentuk baru). Tidak hanya secara politik, tumbuh berkmebangnya dinasti politik juga merugikan secara ekonomi karena dapat mengganggu persaingan usaha yang sehat. Di berbagai negara, khususnya Indonesia, tercatat bahwa pemerintahan cenderung melibatkan kerabat dalam menopang kebijakan ekonominya.

Dinasti politik ditentang di Indonesia karena tidak dibangun berdasarkan sistem meritokrasi yang dinilai cocok dengan iklim politik di Indonesia. Sistem meritokrasi adalah memberikan privilege kepada siapapun yang memiliki prestasi. Meritokrasi dianggap dapat mengikis sistem dinasti politik dan dianggap sebagai sistem yang adil dengan memberikan hak lebih kepada individu-individu yang berprestasi untuk menjadi pemimpin. Anas Urbaningrum, mantan Ketua Umum Parati Demokrat, berpendapat bahwa untuk membangun demokrasi yang utuh maka seharusnya sistem meritokrasi diutamakan. Hal itu penting dalam upaya rekruitmen jajaran pemerintah agar berada pada 
Jurnal Administrasi Negara

ISSN : 2598-4039 (Online)

ISSN : 2302-2231 (Print)

\section{Djoni Gunanto}

Program Studi Ilmu Politik FISIP Universitas

Muhammadiyah Jakarta tempatnya secara profesional berdasarkan kemampuan, kecakapan, dan prestasi yang dimiliki.

\section{Faktor-Faktor Terbentuknya Dinasti Politik}

Terdapat beberapa hal yang mendasari terbentuknya dinasti politik, diantaranya: pertama, mecetnya kaderisasi partai politik dalam merekrut calon/kandidat politik yang berkapasitas dan berkualitas, sehingga partai politik bersikap pragmatisme dengan mengusung calon yang berasal dari keluarga pejabat yang sedang menduduki pemerintahan; kedua, konteks masyarakat yang menjaga status quo, khususnya di tingkat daerah, yang menginginkan kepala daerah untuk berkuasa dengan cara mendorong kerabat atau orang yang dekat dengan kepala daerah untuk menggantikan incumbent.

Kedua faktor umum tersebut adalah awal dari munculnya sikap pro dan kontra terhadap berkembangnya fenomena dinasti politik di Indonesia. Pihak yang kontra terhadap dinasti politik menginginkan adanya pembatasan terhadap sanak saudara elit yang sedang menjabat untuk diikutsertakan dalam kontestasi politik. Sedangkan pihak yang pro terhadap dinasti politik berpandangan bahwa tidak perlu ada pembatasan dalam pencalonan, melainkan sistem perkaderan partai politik saja yang perlu untuk diperbaiki dan dibenahi. Munculnya sikap pro dan kontra masyarakat terhadap berkembangnya dinasti politik tidak terlepas dari kaitannya dengan budaya politik yang berkembang di masyarakat. Dari segi penerimaan publik ataupun pembangunan rezim, budaya politik erat kaitannya dengan preferensi kekuasaan yang dibangun.

\section{Bahaya Dinasti Politik di Indonesia}

Di banyak negara yang terdapat pejabat pemerintah yang membangun dinasti politik memiliki latar belakang yang berbeda-beda, misalnya: dinasti politik Kennedy yang dikenal sebagai dinasti yang cerdas, berkualitas, berintegritas, dan religius; dinasti Nehru-Gandhi, yang dikenal sebagai dinasti yang mempunyai peran penting dalam wujud India modern saat ini. Dinasti polititk Nehru-Gandhi mendominasi Kongres Nasional India dan berjuang untuk kemerdekaan India. Dinasti ini dikenal dengan kesetiannya kepada bangsa dan negara India, sehingga jasa dinasti ini tidak diragukan oleh rakyat India. Dinasti politik di Indonesia justru berbahaya jika tidak dicegah, karena berdasarkan fakta yang terjadi, mekanisme dan ketentuan dalam pencalonan tidak diatur dengan pola yang tepat, sehingga mempengaruhi dan mengancam penyelenggaraan pemerintahan. 
Jurnal Administrasi Negara

ISSN : 2598-4039 (Online)

ISSN : 2302-2231 (Print)

\section{Djoni Gunanto}

Program Studi Ilmu Politik FISIP Universitas

Muhammadiyah Jakarta

Terdapat beberapa
pandang pudut
menggambarkan bahayanya dinasti
politik di Indonesia: pertama,
kekelitik
masuknyatan di Indonesia menyulitkan
mekanisme checks and balances. Dinasti
politik di Indonesia sebatas
mengutamakan kekerabatan, dan dalam
pengambilan kebijakan juga
menguntungkan pihak tertentu saja;
kedua, berkembangnya politik dinasti menyebabkan playing field mengalami ketimpangan karena politik dinasti sudah mampu mengakumulasi pengaruh, kekayaan, penguasaan terhadap wilayah, maupun kontrol ekonomi tertentu, sehingga memungkinkan persentase kemenangan yang potensial dalam kontestasi politik dibandingkan calon lain yang masih memiliki keterbatas dalam sumberdaya dan modal; ketiga, tumbuh suburnya politik dinasti menunjukkan bahwa institusionalisasi kepartaian yang semakin buruk dan menunjukkan kualitas partai politik yang lemah dalam menjalankan fungsinya dalam rekrutmen dan kaderisasi; keempat, kekuatan partai politik semakin melemah karena kekuatan individu kandidat menjadi faktor determinan dalam kemenangan kontestasi. Partai politik mengutamakan calon yang mempunyai hubungan dengan kerabat yang memiliki jabatan politik karena dianggap mumpuni dari segi finansial, popularitas, serta kemampuan dalam memobilisasi massa. Kemenangan dalam kontestasi menjadi prioritas utama partai politik, bukan lagi efektivitas kekuasaan dalam jangka menengah dan panjang, sehingga berbagai cara dapat dilakukan oleh partai politik untuk memastikan terjaminnya kemenangan.

\section{PENUTUP}

Politik dinasti di Indonesia tumbuh berkembang sejak era orde lama, orde baru, hingga era reformasi. Politik dinasti terjadi pada level nasional dan daerah. Politik dinasti di Indonesia dipandang sebagai penyakit dalam demokrasi karena mencederai makna demokrasi yang mengandung makna kebebasan khususnya dalam proses pencalonan dalam kontestasi politik. Sehingga dengan adanya fenomena politik dinasti justru membatasi kebebasan terhadap masyarakat untuk berpartisipasi aktif dalam pencalonan, karena calon yang memiliki hubungan kekeluargaan dengan elit yang masih menjabat akan lebih mudah untuk mendapatkan kemenangan karena memiliki sumberdaya finansial yang lebih kuat, memiliki popularitas, serta mudah memobilisasi massa.

Dinasti politik sejatinya tidak dibenarkan keberadaannya dalam negara demokrasi karena sistem ini telah memotong hak-hak warga negara 
Jurnal Administrasi Negara

ISSN : 2598-4039 (Online)

ISSN : 2302-2231 (Print)

\section{Djoni Gunanto}

Program Studi Ilmu Politik FISIP Universitas

Muhammadiyah Jakarta sehingga negara dikuasai dan dikontrol oleh segelintir orang saja. Padahal negara ini milik bersama, sementara politik dinasti berefek pada penguasaan negara oleh sekelompok elit tertentu, bahkan oleh satu keluarga saja. Regulasi yang mengatur tentang politik dinasti terlalu lemah, bahkan jika kuat masih mudah dilemahkan, sehingga perlu ditegaskan regulasi yang mengatur pencegahan terjadinya dinasti politik di Indonesia.

Politik dinasti sejatinya bisa diterima dan tidak dipersoalkan selama dalam pelaksanaan sistem perekrutan dan pemilihan calon dalam kontestasi politik di Indonesia berjalan secara adil dan profesional. Namun, di Indonesia ditentang karena politik dinasti didasarkan pada asas kekerabatan, bukan atas dasar kapasitas dan kualitas yang dimiliki oleh calon. Sehingga hal itu dapat menjadi acaman terhadap keberlangsungan pemerintahan dalam jangka menengah dan jangka panjang. Oleh karenanya, penentuan calon atau kandidat dalam kontestasi politik di Indonesia harus didasarkan pada sistem meritokrasi, yakni memberikan hak lebih kepada siapapun yang memiliki prestasi dan track record yang baik untuk menduduki kursi-kursi strategis dalam pemerintahan.

\section{REFERENSI}

Buku

Dewi, Susi Fitria. 2017. Sosiologi Politik. Yogyakarta : Gre Publisihing.

Mietzner, Marcus. 2009. Indonesia's 2009 Elections: Populism, Dynasties and the Consolidation of the Party System. Australian : ANU Research Publications. pp. 122.

Garzon, Adela. 2002. "Familism." International Encyclopedia of Marriage and Family, diedit oleh En J. Ponzetti. New York: MacMillan. pp.1-4

\section{Jurnal}

Dal Bo, Ernesto, Pedro Dal Bo and Jason Snyder. 2009. Political Dynasties. Review of Economic Studies. 76, 115 -

142.https://academic.oup.com/rest $\underline{\mathrm{ud} / \text { article- }}$ abstract/76/1/115/1574319

Djati, Wasisto Raharjo. 2013. Revivalisme Kekuatan Familisme dalam Demokrasi: Dinasti Politik di Aras Lokal. Jurnal Sosiologi MASYARAKAT, Vol. 18, No. 2, Juli 2013:203-231.

http://journal.ui.ac.id/index.php/m js/article/view/3726

Eulau, Heinz dan Susan Zlomke. 1999. Harold D. Lasswell's Legacy to Mainstream Political Science: A 
Jurnal Administrasi Negara

ISSN : 2598-4039 (Online)

ISSN : 2302-2231 (Print)

\section{Djoni Gunanto}

Program Studi Ilmu Politik FISIP Universitas

Muhammadiyah Jakarta
Neglected Agenda. Annu. Rev.

Polit. Sci. 1999. 2:75-89.

https://www.annualreviews.org/d

oi/abs/10.1146/annurev.polisci.2.1.7 $\underline{5}$

Park, Tong-Hee. 2009. “The Influence of Familism and Interpersonal Trusts of Korean Public Officials". International Review of Public Administration 9 (1): 121-136. https://www.tandfonline.com/doi/ abs/10.1080/12294659.2004.1080504 4

Prianto, Budhy. 2016. Partai Politik, Fenomena Dinasti Politik dalam Pemilihan Kepala Daerah dan Desentralisasi. Jurnal Administrasi Publik Volume 1, Nomor 2, Oktober 2016. 105-117.

http://jurnal.unmer.ac.id/index.php/jkp $\mathrm{p} /$ article/view/436/270

Tadem, Teresa S Encarnacion and Eduardo C Tadem. 2016. Political Dynasties in The Philippine : Persistent Patterns, Perennial Problems. South East Asia Research. Vol. 24 (3) 328-340. https://www.tandfonline.com/doi/ abs/10.1177/0967828X16659730

Rachman, Yudhi. 2015. Pilkada, Dinasti Politik di Era Desentralisasi (Studi tentang Habitus and Field, Aktor Politik dalam Kontestasi Pilkada Kab. Bangkalan yang Melahirkan Dinasti Politik). Vol 8, No 2 https://journal.trunojoyo.ac.id/dim ensi/article/viewFile/3733/2735

\section{Website}

Daniele, Gianmarco. 2015. Born in the Purple: Political Dynasties and ElectoralSuccess.

http://www.ieb.ub.edu/files/Papers WSFF2015/WSPEPF2015Daniele.p df.

Idntimes.com. 2020. Daftar Nama Dinasti Ratu Atut di Panggung Politik Banten. https://jabar.idntimes.com/news/in donesia/khaerul-anwar-2/namanama-dinasti-ratu-atut-di-bantenregional-jabar/6 diakses pada tanggal 25 Juli 2020.

Kompas.com. 2020. Menyelisik Politik Dinasti Generasi Keempat. https://www.kompas.com/tren/rea d/2019/11/02/135302965/menyelisik -politik-dinasti-generasikeempat?page $=$ all diakses pada tanggal 25 Juli 2020.

Republika.co.id. 2013. Anas Urbaningrum Dukung SBY Jadi Pelopor Meritokrasi Politik. https://nasional.republika.co.id/ber ita/muv2an/anas-urbaningrumdukung-sby-jadi-pelopormeritokrasi-politik diunnduh pada tanggal 25 Juli 2020.

Republika.co.id. 2013. Kisah Dinasti Gandhi-Nehru.

https://www.republika.co.id/berita /dunia-islam/islammancanegara/11/12/22/internasion al/global/13/02/19/migx7j-kisah- 
Jurnal Administrasi Negara ISSN : 2598-4039 (Online) ISSN : 2302-2231 (Print)
Djoni Gunanto

Program Studi Ilmu Politik FISIP Universitas Muhammadiyah Jakarta

dinasti-gandhinehru-i dikases

pada tanggal 26 Juli 2020.

Tempo.co. 2020. Poiitk Dinasti Era Jokowi.

https://kolom.tempo.co/read/13669

94/politik-dinasti-era-

jokowi/full\&view $=$ ok diakses pada tanggal 24 Juli 2020.

Tirto.id. 2019. Sejarah Hidup Fuad Amin: Wafatnya Sang Penguasa Bangkalan, Madura. https://irto.id/sejarah-hidup-fuadamin-wafatnya-sang-penguasabangkalan-madura-eifT diakses pada tanggal 26 Juli 2020. 